\title{
PERSEPSI MASYARAKAT NELAYAN PESISIR TENTANG PENTINGNYA PENDIDIKAN FORMAL DI DESA LATAWE KECAMATAN NAPANO KUSAMBI KABUPATEN MUNA BARAT
}

\author{
Jayatri Manda Sari ${ }^{1}$, La Harudu² \\ ${ }^{1}$ Alumni Pendidikan Geografi FKIP UHO \\ ${ }^{2}$ Dosen Pendidikan Geografi FKIP UHO
}

\begin{abstract}
Abstrak: penelitian ini bertujuan untuk mengetahui persepsi masyarakat nelayan pesisir Desa Latawe tentang pentingnya pendidikan formal dan upaya yang dilakukan pemerintah untuk menyadarkan masyarakat nelayan pesisir Desa Latawe tentang pentingnya pendidikan formal. Penelitian ini menggunakan pendekatan kualitatif deskripstif dengan metode mix metode untuk menggambarkan tentang persepsi masyarakat nelayan pesisir tentang pentingnya pendidikan formal di Desa Latawe. Hasil penelitian diketahui bahwa pandanganmasyarakat nelayan pesisir Latawe tentang pentingnya pendidikan formal masih sangat rendah hal ini disebabkan beberapa faktor diatantaranya faktor pengetahuan, ekonomi yang rendah, motifasi, budaya dan perhatian pemerintah yang masih kurang. Sedangkan upaya yang efektif yang dilakukan pemerintah untuk meningkatkan kesadaran masyarakat nelayan pesisir Desa Latawe tentang pentingnya pendidikan formal adalah pemberdayaan masyarakat dengan tanggapan responden sebanyak 22 atau $73.33 \%$ memberikan tanggapan dilibatkan dalam mendorong anaknya mengikuti pendidikan formal yang diselenggarakan disekolah. Kesimpulan persepsi masyarakat nelayan pesisir desa Latawe terhadap pentingnya pendidikan formal masih rendah dan upaya yang dilakukan pemerintah untuk meningkatkan kesadaran masyarakat nelayan pesisir Desa Latawe dalam memandang pentingnya pendidikan formal mencakup sosialisasi program bantuan pemerintah dalam pendidikan, pemberdayaan masyarakat dan penyelenggaraan pendidikan non formal.
\end{abstract}

Kata Kunci: Persepsi, Masyarakat nelayan Pesisir,Pendidikan formal 
Jurnal Penelitian Pendidikan Geografi Volume 3. No 4 Oktober 2018

\title{
PERCEPTION OF COASTAL FISHERMAN'S PEOPLE ABOUT THE IMPORTANCE OF FORMAL EDUCATION IN THE VILLAGE OF LATAWE SUBSTANCE NAPANO KUSAMBI DISTRICT OF WEST MUNA
}

\author{
Jayatri Manda Sari ${ }^{1}$, La Harudu ${ }^{2}$ \\ ${ }^{1}$ Geography Educational Alumni Halu Oleo University \\ ${ }^{2}$ Geography education lecturer at Halu Oleo University
}

This study aims to determine the perception of the community of coastal fishermen in the village of Latave about the importance of formal education and the efforts made by the government to awaken the coastal fishing communities of the village of Latawe about the importance of formal education. This study uses a descriptive qualitative approach with a blending method to describe the perceptions of the community of coastal fishermen about the importance of formal education in the village of Latawe. The results of the research show that the opinion of the coastal fishing community of Latave about the importance of formal education is still very low due to several factors, such as low knowledge, economics, motivation, culture and government attention. Although the effective efforts of the government to raise awareness of the community of coastal fishermen in the village of Latawe about the importance of formal education is the empowerment of the community with a response rate of 22 or $73.33 \%$ to provide responses related to encouraging their children to formal schooling. Conclusion, the perception of the community of coastal fishermen in the village of Latawe on the importance of formal education is still low and the efforts undertaken by the government to raise awareness of the community of coastal fishermen in the village of Let in connection with the importance of formal education include the socialization of state assistance programs in the field of education, empowerment of communities and non-formal education.

\section{Keywords: Perception, Coastal Fisherman Society, Formal Education}

\section{PENDAHULUAN}

Pendidikan saat ini merupakan hal yang sangat penting dan tidak dapat dipisahkan dari kehidupan manusia.Pendidikan memberikan kontribusi yang sangat besar terhadap kemajuan suatu bangsa dan merupakan wahana dalam menerjemahkan pesan-pesan konstitusi serta merupakan sarana dalam membangun watak bangsa (Nation Character Building). Pendidikan merupakan sebuah proses yang dengan sengaja dilaksanakan, bertujuan untuk mencerdaskan bangsa. Melalui proses pendidikan akanterbentuk sosok-sosok individu sebagai sumber daya manusia yang akan berperan besar dalam proses pembangunan bangsa dan negara. Oleh karena itu peran pendidikan sangat penting, sebab pendidikan merupakan kunci utama untuk menciptakan sumber daya manusia yang berkualitas. (Mulyono 2010:15)

Visi dan orientasi pendidikan sebagaimana diuraikan di atas tidak selalu berjalan sesuai apa yang diharapkan baik pemerintah maupun masyarakat. Kondisi berbeda justru terjadi dalam beberapa kelompokmasyarakat yaitu adanya 
situasi yang pasif dalam masyarakat untuk melibatkan diri atau anggota keluarganya dalam menyukseskan pemerataan pendidikan. Kondisi ini juga masih terjadi pada sebahagian masyarakat pesisir di Desa Latawe Kecamatan Napabalono Kabupaten Muna Barat.

Berdasarkan observasi awal peneliti menemukan gambaran dan fakta sosial yang cukup ironis, yaitu bahwa pada saat masyarakat pada umumnya memiliki antusiaslissme yang tinggi pada keinginan menempuh pendidikanformal yang lebih tinggi justru pada masyarakat nelayan pesisir di Desa Latawe masyarakatnya pasif dan tidak memiliki motivasi kuat untuk mengikuti pendidikan formal sebagai jalur yang disediakan Negara melalui pemerintah untuk meningkatkan sumber daya manusia. Adapun jumlah anak yang putus sekolah yang diperoleh peneliti pada observasi awal tanggal 20 Mei 2018 sebanyak 20 orang. (Penelitian awal pada bulan Jayatri April 2018)

Berdasarkan wawancara di atas maka menguatkan bahwa ada masalah yang cukup serius pada masyarakat Desa Latawe dalam memandang pentingnya pendidikan formal sebagai sarana dalam meningkatkan sumber daya manusia. Penjelasan dalam uraian di atas maka menarik untuk dikaji lebih lanjut melalui cara yang empirik dan ilmiah melalui penelitian dengan judul Persepsi masyarakat nelayan pesisr tentang pentingnya pendidikan formal di Desa Latawe Kecamatan Napano Kusambi Kabupaten Muna Barat

Berdasarkan fakta di atas tentang persepsi masyarakat pesisir nelayan pentingnya pendidikan formal maka menurutMenurut (Bimo Walgito, 2003:3). Persepsi merupakan proses yang didahului oleh proses pengindraan, yaitu merupakan proses diterimanya stimulus oleh individu melalui alat indera atau disebut juga proses sensoris. Sedangkan Sarlito Wirawan Sarwono, 2000:60 mengungkapakan dalam bukunya "Psikologi Lingkungan" mengatakan bahwa persepsi adalah jika jumlah pengindraan disatukan dan dikoordinasikan di dalam pusat syaraf yang lebih tinggi (otak) sehingga manusia dapat mengenali dan menilai objek-objek.

Pandangan lain tentang persepsi juga dijelaskan oleh Thoha, 1999:24 bahwa persepsi pada hekekatnya ialah proses kognitif yang dialami oleh setiap orang dalam memahami setiap informasi tentang lingkungannya baik melalui penglihatan, pendengaran, penghayatan, perasaan dan penciuman. Menurut Slameto, 2010:102 persepsi ialah proses yang menyangkut masuknya pesan atau informasi ke dalam otak manusia, melalui persepsi manusia terus menerus mengadakan hubungan dengan lingkungannya. Hubungan ini dilakukan lewat inderanya yaitu indera penglihat, pendengar, peraba, perasa dan pencium.

Sedangkan konsep masyarakat menurut Menurut Roucek danWarren,1984: 37 masyarakat merupakan sekelompok manusia yang memiliki rasa kesadaran bersama di manamereka berdiam pada daerah yang sama, yang sebagian besar atau seluruh wargannya memperlihatkan adanya adat kebiasaan danaktivitas yang sama. Masyarakat adalah sekelompok individu yang bertampat 
tinggal dalamsuatu daerah tertentu serta dapat berinteraksi dengan individu lainnya delam kurun waktu yang cukup lama.

$\begin{array}{rlr}\text { Pendapat } & \text { lain } & \text { menurut } \\ \text { Koenjaraningrat } & \text { 2012: } & 120\end{array}$ masyarakat adalah sekumpulan orang yang saling berinteraksi, dan suatu kelompok orang yang sama identifikasinya, teratur sedemikian rupa di dalammenjalankan segala sesuatu yang diperlukan bagi kehidupan bersama secara harmonis. Selanjutnya pengertian masyarakat yang diungkapkan oleh Seorang ahli antropologiR. Linton,1954:80 setiap selompok manusia yang telah cukup lama hidup danbekerja sama, sehingga mereka itu dapat mengorganisasikan dirinya danberfikir tentang dirinya sebagai satu kesatuan sosial dengan batas-batas tertentu

Pembahasan dalam penelitian ini yang tidak kalah penting menjadi obyek pembahasan yaitu pendidikan formal. Oleh karena itu maka konsep pendidikan menjadi penting untuk dibahasa maka oleh karena itu menurut UU Sistem Pendidikan Nasional nomor 20 tahun 2003: "Pendidikan adalah usaha sadar dan terencana untuk mewujudkan suasana belajar dan proses pembelajaran agar peserta didik secara aktif mengembangkan potensi dirinya untuk memiliki kekuatan spiritual keagamaan, pengendalian diri, kepribadian, kecerdasan, akhlak mulia, serta ketrampilan yang diperlukan dirinya, masyarakat, bangsa, dan negara" (UU sisdiknas no 20 th 2003:3).

Menurut Riva ${ }^{e} i$ dan Murni, yang dikutip oleh Abdul Syukur (2014 : 20), adalah proses secara sistematis untuk mengubah tingkah laku seseorang ke arah yang lebih baik. sehingga untuk menunjang keberhasilan seorang dalam dunia pendidikan maupun dunia kehidupanyang layak, sudah seharusnya pendidikan diajarkan orang tuanya dimulai ketika anak masih kecil. Dalam UU Sistem Pendidikan Nasional No 20 Tahun 2003 disebutkan bahwa pendidikan terbagi atas tiga yaitu Pendidikan Formal, pendidikan non formal dan pendidikan informal adapun lebih jelasnya yaitu sebagai berikut:

Pendidikan Formal adalah jalur pendidikan yang terstruktur dan berjenjang yang terdiri atas pendidikan dasar, pendidikan menengah, dan pendidikan tinggi.Sedangkan Pendidikan Non Formal adalah jalur pendidikan diluar pendidikan formal yang dapat dilaksanakan secara terstruktur dan berjenjang.Pendidikan Informal adalah jalur pendidikan keluarga dan lingkungan. (UU Sisdiknas No 20 Th 2003: 4).

Dilihat dari pengertian diatas, dapat diketahui bahwa pendidikan tidak terbatas pada pendidikan di lingkungan sekolah saja, yang dalam bahasa akademik disebut dengan pendidikan formal. Lingkungan keluarga pun bisa dikategorikan sebagai tempat berlangsungnya pendidikan. Pondokpondok pesantren juga bisa dikategorikan sebagai tempat berlangsungya pendidikan.Akan tetapi dalam skripsi ini yang lebih dibahas khususnya adalah pendidikan formal yang berarti jalur pendidikan yang terstruktur dan berjenjang yang terdiri atas pendidikan dasar, pendidikan menengah, dan pendidikan tinggi. 


\section{METODE PENELITIAN}

Jenis penelitian $\begin{array}{r}\text { yang } \\ \text { adalah }\end{array}$
dilakukan oleh penulis
lapangan (field research) $\begin{array}{r}\text { dengan } \\ \text { menggunakan metode penelitian mix }\end{array}$
metode. Menurut Craswell 2010:5,
penelitian campuran (mix methods)
adalah merupakan pendekatan
penelitian dengan mengkombinasi
antara dua metode penelitian
kualitatif dan metode kuantitatif.
Sedangkan menurut Sugiyono
(2011:404) bahwa, Metode penelitian
kombinasi (mixed methods) adalah
suatu metode penelitian yang
mengkombinasikan atau
menggabungkan antara metode
kuantitatif dan metode kualitatif untuk
digunakan secara bersama-sama dalam
suatu kegiatan penelitian sehingga
diperoleh data yang lebih
komprehensif, valid, reliabel dan
objektif.

Penelitian ini menggunakan
instrument angket berupa data
kuantitatif untuk mengetetahui
presespsi $\begin{aligned} & \text { masyarakat tentang } \\ & \text { pentingnya pendidikan formal }\end{aligned}$
sedangkan data wawancara
menggunakan pedoman wawancara
untuk memperoleh data tentang
persepsi masyarakat pesisir Desa
Latawe tentang pentinya pendidikan
formal.

\section{Populasi Dan Sampel}

Populasi dalam penelitian adalah merupakan keseluruhan dari obyek maupun subyek yang akan diteliti. Adapun yang menjadi populasi dalam penelitian ini adalah seluruh masyarakat pesisir Desa Latawe Kecamatan Napano Kusambi Kabupaten Muna barat. Dan Sampel adalah bagian yang mewakili populasi atau merupakan subyek atau obyek representasi dari populasi. Adapun sampel dalam penelitian ini adalah 30 orang masyarakat pesisir Desa Latawe yang diperoleh dengan menggunakan proposive sampling atau dengan cara penunjukan.

\section{Informan Penelitian}

Dalam penelitian ini peneliti juga menggunakan informan penelitian sebanyak 5 orang yang terdiri dari anggota masyarakat pesisr Desa Latawe dan pemerintah Desa setempat yang terdiri dari Kepala Desa Latawe, Tokoh Masyarakat, Tokoh pemuda dan anggota masyarakat Pesisir Desa Latawe

\section{Teknik Pengumpulan Data}

Informasi melalui $\begin{array}{r}\text { penelitian } \\ \text { teknik }\end{array}$
dikumpulkan melalui berikut :
pengumpulan data sebagai beri, wawncara, angket dan
Observasi,
dokumentasi.

\section{Teknik Analisis Data}

Data dalam penelitian ini yang diperoleh peneliti melalui angket maka akan dianalisis menggunakan skala Likert untuk mengolah penghitungan angket. Sugiyono dalam bukunya Metode penelitian kualitatif kuantitatif R\&D (2011 : 93) mengemukakan bahwaSkala Likert digunakan untuk mengukur sikap, pendapat dan persepsi seseorang atau sekelompok orang tentang fenomena sosial, fenomena sosial ini telah ditetapkan secara spesifik oleh peneliti dan selanjutnya disebut sebagai variable penelitian. 
Dengan menggunakan skala likert variable yang akan diukur dijabarkan menjadi indikator variabel, dan seterusnya indikator tersebut dijadikan sebagai tolak ukur untuk menyusun bagian-bagian yang dapat dijadikan pertanyaan atau pernyataan. Jawaban dari setiap bagian tersebutmempunyai gradasi dari yang sangat positif hingga yang sangat negatif, yang dapat berupa kata - kata antara lain :

Adapun penilaian skor dari jawaban setiap pernyataan responden yaitu sebagai berikut:

1. Sangat setuju/ diberi skor 5

2. Setuju/ patuh diberi skor 4

3. Ragu-ragu diberi skor 3

4. Tidak setuju diberi skor 2

5. Sangat tidak setuju skor 1

(Sugiyono,2011 : 94)

Instrumen penelitian yang menggunaka skala likert dapat dibuat dalam bentuk checklist ataupun pilihan ganda.Datakuantitatifdiperoleh melalui angket disajikan dalam tabel frekuensi menurut Sugiyono (2012).

\section{HASIL PENELITIAN}

\section{PersepsiMasyarakat Nelayan Pesisir Desa Latawe Terhadap Pentingnya Pendidikan Formal}

Pendidikan menduduki posisi sentral dalam pembangunan karena sasarannya adalah peningkatan kualitas sumberdaya manusia, oleh sebab itu pendidikan juga merupakan alur tengah dari seluruh sektor pembangunan. Pembangunan dalam keterkaitannya dengan pengembangan sumberdaya manusia yang berarti bahwa pembangunan adalah tidak semata-mata pembangunan material dan fisik tetapi juga pembangunan spiritual dan keberhasilan pembangunan dapat tercermin dari sisi ekonomi atau material dan juga sisi spiritual, yang terlihat bahwa esensi pembangunan bertumpu dan berpangkal pada sisi manusia nya, dengan demikian yang menjadi tujuan akhir pembangunan adalah manusia.

Manusia sebagai modal
pembangunan tidak lepas dari
pendidikan sehingga pendidikan
merupakan salah satu tolak ukur
dalam melihat keberhasilan
pembangunan. Berdasarkan uraiain di
atas maka semakin mempertegas
tentang peranan pendidikan dalam
peningkatan sumber daya manusia,
namun demikian pemahaman tentang
pentingnya pendidikan dalam
peningkatan sumber daya manusia
belum dapat dipahami secara
menyeluruh oleh semua kalangan
masyarakat. Kondisi ini terjadi pada
masyarakat pesisir suku bajo di
DesaLatawe. Adapun lebih jelasnya
tentang persepsi masyarakat nelayan
pesisir DesaLatawe dapat dijelaskan
berdasarkan variabel yang
mempengaruhi sebagai berikut:

\section{Faktor Pengetahuan Masyarakat}

Faktor

pengetahuan mempengaruhi seseorang dalam memberikan pandangan tentang suatu obyek yang dinilai. Berdasarkan hasil angket yang diperoleh peneliti tentang pengetahuan masyarakat dalam hubunganya dengan persepsi masyarakat DesaLatawe tentang pentingnya pendidikan formal dapat dilihat pada tabel berikut: 
Jurnal Penelitian Pendidikan Geografi Volume 3. No 4 Oktober 2018

Tabel 3.1

Faktor Pengetahuan Mempengaruhi PersepsiMasyarakat Nelayan Pesisir Desa Latawe Tentang Pentingnya Pendidikan Formal PENILAIAN $\quad$ Frekuensi (F) Persentase

(P)

Sangat Setuju

\begin{tabular}{lcc}
\hline Setuju & 4 & $13.33 \%$ \\
\hline Netral/Ragu-Ragu & 16 & $53.33 \%$ \\
\hline Tidak Setuju & 10 & $33.33 \%$ \\
\hline Sangat Tidak Setuju & & \\
\hline \multicolumn{1}{c}{ Jumlah } & $\mathbf{3 0}$ & $\mathbf{1 0 0 \%}$ \\
\hline
\end{tabular}

Sumber : Hasil Angket 2018

Berdasarkan Tabel diatas maka menunjukan bahwa sebanyak 16 orang atau $53.33 \%$ responden menjawab ragu-ragu bahwa pendidikan formal sangat penting, selanjutnya 10 orang atau $33.33 \%$ yang menjawab Tidak setuju dan 4 orang atau $13.33 \%$ responden menjawab setuju. Dari data di atas menunjukan bahwa hanya ada 4 orng responden yang memiliki pengetahuan yang cukup bahwa pendidikan formal sangat penting sedangkan 16 orang menjawab ragu-ragu tidak memiliki pengetahuan bahwa pendidikan formal itu sangat penting bahkan 10 orang menjawab tidak setuju bahwa pendidikan formal itu penting.

Berdasarkan data di atas maka menurut penulis bahwa masyarakat suku bajo yang berada di Desa Latawe Kecamatan Napano Kosambi umumnya tidak mengikuti pendidikan formal karena pengetahuan mereka yang tidak memadai tentang pentingnya pendidikan formal. Oleh karena itu dari jawaban responden tentang pentingnya pendidikan formal sebagian besar responden menjawab ragu-ragu bahkan tidak setuju dan hanya 4 responden yang memberikan jawaban setuju.

\section{Faktor Ekonomi}

Kemapanan ekonomi juga memberikan pengaruh terhadap pandangan masyarakat dalam memandang pentinya pendidikan formal. Ekonomi masyarakat yang baik tentu dapat membatu siswa dalam menempuh pendidikan formal dalam hal membantu siswa untuk melengkapi sarana dan prasarana belajarnya sehingga proses belajarnya dapat berjalan secara efektif dan efisien. Kondisi ekonomi yang sangat penting ini menjadi salah satu faktor yang mempengaruhi pandangan masyarakat DesaLatawe dalam memberikan tanggapan terhadap pentingnya pendidikan formal.

Berdasarkan hasil angket yang diperoleh dalam penelitian ini tentang tanggapan responden tentang faktor ekonomi dalam hubunganya dengan pentingnya pendidikan formal dapat dilihat pada tabel berikut: 
Tabel 3.2

Faktor EkonomiMempengaruhi PersepsiMasyarakat Nelayan Pesisir Desa Latawe Tentang Pentingnya Pendidikan Formal

\begin{tabular}{lcc}
\hline \multicolumn{1}{c}{ PENILAIAN } & Frekuensi (F) & Persentase (P) \\
\hline Sangat Setuju & 20 & $66.66 \%$ \\
\hline Setuju & 6 & $20.00 \%$ \\
\hline Netral/Ragu-Ragu & 4 & $13.33 \%$ \\
\hline Tidak Setuju & & \\
\hline Sangat Tidak Setuju & & $\mathbf{1 0 0 \%}$ \\
\hline \multicolumn{1}{c}{ Jumlah } & $\mathbf{3 0}$ &
\end{tabular}

Sumber : hasil angket 2018

Berdasarkan Tabel diatas maka menunjukan bahwa sebanyak 20 orang atau $66.66 \%$ responden menjawab sangat setuju bahwa faktor ekonomi sangat mempengaruhi masyarakat nelayan pesisir untuk tidak menempuh pendidikan formal di sekolah, selanjutnya 6 orang atau $20.00 \%$ yang menjawab setuju dan 4 orang atau $13.33 \%$ responden menjawab tidak setuju bahwa faktor ekonomi sebagai faktor yang mempengaruhi masyarakat untuk tidak menempuh pendiidkan formal di sekolah.

Berdasarkan data di atas maka dapat menggambarkan bahwa faktor ekonomi sangat mempengaruhi persepsi masyarakat bajau dalam memandang pentingnya pendidikan formal, halini dapat dilihat dari jawaban 20 orang responden menjawab sangat setuju sedangkan 6 orang mennjawab ragu-ragu dan hanya 4 orang responden memberikan jawabn tidak setuju bahwa faktor ekonomi sebagai faktor yang mmpengaruhi pandangan masyarakat.
Maka oleh karena itu menurut penulis bahwa masyarakat suku bajo yang berada di Desa Latawe Kecamatan Napano Kosambi umumnya tidak mengikuti pendidikan formal karena faktor ekonomi. Hal ini terlihat dari jawaban responden di atas bahwa masyarakat suku bajo di DesaLatawe tidak mengikuti pendidikan formal sebagian besar responden menjawab karena faktor ekonomi yang tidak mendukung.

\section{Faktor Motifasi}

Motifasi adalah salah satu aspek yang juga mempengaruhi dari sebuah persepsi kelompok masyarakat karena motifasi menjadi sebuah stimulus yang dapat memberikan dorangan untuk melakukan sesuatu sebagai bentuk reaksi dari stimulus yang didapatakan. Hubungan antara motifasi dan persepsi masyarakat DesaLatawe dalam memandang pentingnya pendidikan berdasarkan hasil angket dapat dilihat pada tabel berikut: 
Jurnal Penelitian Pendidikan Geografi Volume 3. No 4 Oktober 2018

Tabel 3.3

Faktor Motifasi Mempengaruhi PersepsiMasyarakat Nelayan Pesisir Desa Latawe Tentang Pentingnya Pendidikan Formal

\begin{tabular}{ccc}
\hline PENILAIAN & Frekuensi (F) & Persentase (P) \\
\hline Sangat Setuju & & \\
\hline Setuju & 16 & $53.33 \%$ \\
\hline Netral/Ragu-Ragu & 4 & $13.33 \%$ \\
\hline Tidak Setuju & 10 & $33.33 \%$ \\
\hline Sangat Tidak Setuju & & \\
\hline Jumlah & $\mathbf{3 0}$ & $\mathbf{1 0 0 \%}$ \\
\hline
\end{tabular}

Sumber : hasil angket 2018

Berdasarkan Tabel diatas maka menunjukan bahwa sebanyak 16 orang atau $53.33 \%$ responden menjawab setuju bahwa tidak memiliki motifasi untuk menempuh pendidikan formal di sekolah, selanjutnya 4 orang atau $13.33 \%$ yang menjawab netral dan 10 orang atau $13.33 \%$ responden menjawab tidak setuju bahwa tidak mendapatkan motifasi sebagai faktor yang mempengaruhi masyarakat untuk tidak menempuh pendiidkan formal di sekolah.

Berdasarkan data di atas diketahui bahwa faktor motifasi cukup berpengaruh dalam mempengaruhi persepsi masyarakat Bajau dalam memandang pentingnya pendidikan formal hal ini dapat dilihat dari jawaban responden sebayak 16 setuju dan 4 orang responden menjawab ragu-ragu, serta 10 orang menjawab Tidak setuju. Meskipun 10 orang responden menjawab tidak setuju namun jawabn yang setuju tetap lebih besar maka menurut penulis bahwa masyarakat suku bajo yang berada di
Desa Latawe Kecamatan Napano Kosambi sebagian besar setuju bahwa tidak memiliki motifasi untuk mengikuti pendidikan formal disisi lain terdpat sebagian yang tidak setuju bahwa bukan karena faktor tidak memiliki motifasi tetapi lebih karena masalah keterbatasan ekonomi. Oleh karena itu dari jawaban responden tersebut di atas dapat dipahami bahwa masyarakat suku bajo di DesaLatawe tidak mengikuti pendidikan formal sebagian besar responden menjawab selain karena tidak adanya motifasi untuk mengikuti pendidikan formal juga karena masalah ekonomi yang tidak mendukung.

\section{Faktor Budaya}

Faktor budaya juga menjadi aspek yang mempengaruhi presespsi masyarakat DesaLatawe dalam memandang pentingnya pendidikan formal. Adapun lebih jelasnya tentang persepsi masyarakat DesaLatawe dalam hubunganya dengan penagruh budaya dapat dlihat pada tebel berikut: 
Tabel 3.4

Faktor Budaya Mempengaruhi PersepsiMasyarakat Nelayan Pesisir Desa Latawe Tentang Pentingnya Pendidikan Formal PENILAIAN $\quad$ Frekuensi (F) Persentase

(P)

Sangat Setuju

\begin{tabular}{lcc}
\hline Setuju & 4 & $13.33 \%$ \\
\hline Netral/Ragu-Ragu & 6 & $20.00 \%$ \\
\hline Tidak Setuju & 20 & $66.66 \%$ \\
\hline Sangat Tidak Setuju & & \\
\hline \multicolumn{1}{c}{ Jumlah } & $\mathbf{3 0}$ & $\mathbf{1 0 0 \%}$
\end{tabular}

Sumber : hasil angket 2018

Berdasarkan Tabel diatas maka menunjukan bahwa sebanyak 20 orang atau $66.66 \%$ responden menjawab Tidak setuju bahwa faktor budaya mempengaruhi pandnagan masyarakat untuk menempuh pendidikan formal di sekolah, selanjutnya 6 orang atau $20.00 \%$ yang menjawab netral dan 4 orang atau $13.33 \%$ responden menjawab setuju bahwa budaya sebagai salah satu faktor yang mempengaruhi masyarakat DesaLataweuntuk tidak menempuh pendiidkan formal di sekolah.

Berdasarkan data di atas maka dapat dijelaskan bahwa sebagian besar yaitu 20 orang responden Tidak setuju tentang faktor budaya sebagai faktor yang mempengaruhi persepsi masyarakat bajau tentang pentingnya pendidikan formal dan hanya 4 orang yang memberikan jawaban setuju serta 6 orang menjawab ragu-ragu. Analisis lebih lanjut menurut penulis meskipun pada umumnya responden masyarakat memberikan tanggapan tidak setuju bahwa faktor budaya menjadi faktor yang tidak mempengaruhi namun dalam pandangan penulis budaya tetap saja memberikan pengaruh meskipun tidak secara signifikan.Kondisi dalam pandangan penulis melihat bahwa kultur yang ada pada masyarakat pesisir DesaLatawe umumnya tidak menempuh pendidikan sehingga ini telah menjadi kulture secara turun temurun dan tidak ada budaya kompetitf untuk menempuh pendidikan formal melalui sekolah.

\section{Faktor Perhatian}

Faktor perhatian juga menjadi salah satu aspek yang mempengaruhi persepsi. Adapun yang dimaksud penulis yaitu perhatian yang diberikan pemerintah kepada masyarakat pesisir DesaLatawe dalam hal pentingnya pendidikan formal. Adapun lebih jelasnya tentang faktor perhatian yang mempengaruhi persepsi masyarakat dalam memandang pentingnya pendidikan formal di DesaLatawe dapat dilihat pada tabel berikut: 
Tabel 3.5

Faktor Perhatian PemerintahMempengaruhi PersepsiMasyarakat Nelayan Pesisir Desa Latawe Tentang Pendidikan Formal

\begin{tabular}{lcc}
\hline \multicolumn{1}{c}{ PENILAIAN } & Frekuensi (F) & $\begin{array}{c}\text { Persentase } \\
(\mathbf{P})\end{array}$ \\
\hline Sangat Setuju & 5 & $16.66 \%$ \\
\hline Setuju & 17 & $56.66 \%$ \\
\hline Netral/Ragu-Ragu & 5 & $16.66 \%$ \\
\hline Tidak Setuju & 3 & $10.00 \%$ \\
\hline Sangat Tidak Setuju & & \\
\hline \multicolumn{1}{c}{ Jumlah } & $\mathbf{3 0}$ & $\mathbf{1 0 0 \%}$ \\
\hline
\end{tabular}

Sumber : hasil angket 2018

Berdasarkan Tabel diatas maka menunjukan bahwa sebanyak 17 orang atau $56.66 \%$ responden menjawab setuju bahwa tidak adanya perhatian yang maksimal oleh pemerintah mempengaruhi persepsi masyarakat nelayan pesisir dalam pandanganya untuk menempuh pendidikan formal di sekolah, selanjutnya 5 orang atau $16.66 \%$ yang menjawab sangat setuju bahwa perhatian pemerintah yang masih Tidak menjadi salah satu aspek yang mempengaruhi persepsi dan 5 orang atau $16.66 \%$ responden menjawab netral serta 3 orang atau $10 \%$ responden memberikan tanggapan Tidak setuju bahwa Tidaknya perhatian pemerintah sebagai faktor yang mempengaruhi masyarakat untuk tidak menempuh pendiidkan formal di sekolah.

Berdasarkan data di atas maka dapat diketahui bahwa sebagian besar responden memberikan tanggapan bahwa faktor perhatian pemerintah cukup bersar memberikan pengaruh terhadap persepsi masyarakat nelayan pesisir desa Latawe terhadap pentingnya pendidikan formal. Hal ini dapat dilihat dari jumlah jawaban responden sebanyak 17 orang menjawab setuju dan 5 orang menjawab sangat setuju.
Sedangkan 5 orang menjawab raguragu dan 3 orang menjawab Tidak setuju adalah rsponden yang memiliki alasan lain tentang faktor yang mempengaruhi persepsi masyarakat nelayan pesisir desa Latawe terhadap pentingnya pendidikan formal.

Upaya Pemerintah dalam Meningkatkan

Masyarakat

Kesadaran

PesisirDesaLatawe

Nelayan

Pentingnya Pendidikan Formal

Pendidikan sejatinya adalah hak setiap warga negara untuk memperolehnya sebagai bagian dari amanat konstitusi bahwa negara memiliki kewajiban dalam mencerdaskan kehidupan bangsa. Pada faktanya meskipun pendidikan adalah merupakan hak warga negara namun tidak setiap warga negara mampu untuk mengakses kesempatan pendidikan dengan berbagai faktor yang menjadi dasar penyebabnya. Penyelenggaraan pendidikan formal melalui sekolah adalah merupakan bentuk tanggung jawab negara dalam upaya mencerdaskan kehidupan bangsa melalui pendidikan. Pernyataan di atas juga terjadi di DesaLatawe Kecamatan Napano Kusambi tentang upaya pemerintah dalam meningkatkan kesadaran 
masyarakat dalam memandang pendidikan formal sebagai hal yang penting. Adapun lebih jelasnya tentang upaya pemerintah dalam meningkatkan kesadaran masyarakat di DesaLatawe tentang pentingnya pendidikan formal dapat dijelaskan sebagai berikut:

\section{Sosialisasi Program Bantuan Pemerintah dalam Pendidikan}

Sosialisasi adalah salah satu langkah yang ditempuh pemerintah untuk meningkatkan kesadaran masyarakat DesaLatawe dalam meningkatkan kesadaran masyarakat tentang pentingnya pendidikan formal. Program sosialisasi diharapkan mampu meningkatkan kesadaran masyarakat untuk memandang pendidikan formal sebagai salah satu hal yang penting dalam upaya peningkatan sumber daya manusia di DesaLatawe. Adapun lebih jelasnya mengenai sosialisasi pemerintah dalam upaya meningkatkan kesadaran masyarakat tentang pentingnya pendidikan formal dapat dilihat pada tabel berikut:

Tabel 4.6

Sosialisasi Sebagai Upaya Pemerintah dalam Meningkatkan Kesadaran Masyarakat Nelayan Pesisir Tentang Pentingnya Pendidikan Formal

\begin{tabular}{lcc}
\hline \multicolumn{1}{c}{ PENILAIAN } & Frekuensi (F) & Persentase (\%) \\
\hline Sangat Setuju & & \\
\hline Setuju & 10 & $33.33 \%$ \\
\hline Netral/Ragu-Ragu & 16 & $53.33 \%$ \\
\hline Tidak Setuju & 4 & $13.33 \%$ \\
\hline Sangat Tidak Setuju & & \\
\hline Jumlah & $\mathbf{3 0}$ & $\mathbf{1 0 0 \%}$ \\
\hline
\end{tabular}

Sumber : hasil angket 2018

Berdasarkan Tabel diatas maka menunjukan bahwa sebanyak 10 orang atau $33.33 \%$ responden menjawab setuju bahwa sosialisasi program bantuan pemerintah dalam pendidikan baik Prograam Indonesia Pintar (PIP) maupun Bantuan Operasional Sekolah (BOS) selanjutnya 16orang atau $53.33 \%$ ragu-ragu bahwa sosialisasi program pemerintah dalam pendidikan selalu dilakukan dan 4 orang atau $13.33 \%$ responden menjawab Tidak setuju bahwasosialisasi program pendidikan selalu dilakukan dalam rangka mengingkatkan kesadaran masyarakat dalam mengubah pradigma masyarakat dalam memandang pentingnya pendidikan formal.
Berdasarkan keterangan di atas maka dapat dipahami bahwa upaya yang dilakukan pemerintah dalam meningkatkan kesadaran masyarakat di Desa Latawe tentang pentingnya pendidikan formal tidak begitu efektif hal ini dapat dilihat dengan respon masyarakat yang masih rendah dalam mengikuti pendidikan formal.

\section{Pemberdayaan Masyarakat}

Upaya pemerintah dalam meningkatkan kesadaran masyarakat tentang pentingnya pendidikan formal di Desa Latawe juga dilakukan melalui pemberdayaan masyarakat. Pemberdayaan yang dimaksud adalah pelibatan orang tua anak untuk 
mendorong ananknya mengikuti pendidikan formal disekolah. Hal ini dilakukan oleh pemerintah Desa maupun pihak sekolah untuk melibatkan orang tua anak agar lebih memberikan memberikan dorongan dan kesempatan kepada anaknya untuk mengikuti pendidikan formal di sekolah. Adapun lebih jelasnya tentang pemberdayaan masyarakat yang melibatkan orang tua siswa dapat dilihat pada tabel berikut:

Tabel 3.7

Pemberdayaan Masyarakat Sebagai Upaya Pemerintah dalam Meningkatkan KesadaranMasyarakat Nelayan Pesisir Tentang Pentingnya Pendidikan Formal

\begin{tabular}{lcc}
\hline \multicolumn{1}{c}{ PENILAIAN } & Frekuensi (F) & Persentase (\%) \\
\hline Sangat Setuju & 10 & $33.33 \%$ \\
\hline Setuju & 15 & $50.00 \%$ \\
\hline Netral/Ragu-Ragu & & \\
\hline Tidak Setuju & 5 & $16.66 \%$ \\
\hline Sangat Tidak Setuju & & $\mathbf{1 0 0 \%}$ \\
\hline \multicolumn{1}{r}{ Jumlah } & $\mathbf{3 0}$ & \\
\hline
\end{tabular}

Sumber : hasil angket 2018

Berdasarkan Tabel diatas maka menunjukan bahwa sebanyak 10 orang atau $50 \%$ responden menjawab setuju bahwa pemberdayaan masyarakat melalu cara melibatkan orang tua dilakukan oleh pemerintah selanjutnya 10orang atau $33.33 \%$ menjawab sanagt setuju bahwa pelibatan orang tua anak untuk mendorong anaknya mengikuti pendidikan formal dan 5orang atau $16.66 \%$ responden menjawab Tidak setuju dilibatkan dalam mendorong anaknya untuk mengikuti pendidikan formal yang dilakukan dalam rangka mengingkatkan kesadaran masyarakat nelayan pesisir dalam mengubah pradigma masyarakat dalam memandang pentingnya pendidikan formal.

\section{Penyelenggaraan Pendidikan Non Formal}

Penyelenggaraan pendidikan non formal juga adalah salah satu upaya yang dilakukan dalam menumbuhkan kesadaran masyarakat di DesaLatawe tentang pentingnya pendidikan bagi generasi muda. Melalui pendidikan non formal masyarkat dapat diajarkan tentang skill atau keterampilan dalam mengelola hasil laut termasuk keahlian lainya. Selain itu pemerintah juga menfasilitasi tentang ujian penyetaraan Paket A untuk tingkat SD, Paket B tingkat SMP dan Paket C untuk tingkat SMA. Berbagai upaya tersebut diharapakan menjadi sarana untuk menumbuhkan kesadaran bahwa pendidikan adalah sebuah kebutuhan. Adapun lebih jelasnya tentang penyelenggaran pendidikan non formal dapat dilihat berdasarkan tanggapan responden pada tabel berikut: 
Tabel 3.8

Penyelenggaran Pendidikan Non Formal Sebagai Upaya Pemerintah dalam Meningkatkan KesadaranMasyarakat Nelayan Pesisir Tentang Pentingnya Pendidikan Formal

\begin{tabular}{ccc}
\hline PENILAIAN & Frekuensi (F) & Persentase (\%) \\
\hline Sangat Setuju & & \\
\hline Setuju & 18 & $60.00 \%$ \\
\hline Netral/Ragu-Ragu & 8 & $26.66 \%$ \\
\hline Tidak Setuju & 4 & $13.33 \%$ \\
\hline Sangat Tidak Setuju & & \\
\hline Jumlah & $\mathbf{3 0}$ & $\mathbf{1 0 0 \%}$ \\
\hline
\end{tabular}

Sumber : hasil angket 2018

Berdasarkan Tabel diatas maka menunjukan bahwa sebanyak 18 orang atau $60.00 \%$ responden menjawab setuju bahwa pemerintah menfasilitasi penyelenggaraan pendidikan non formal termasuk program penyelenggaraan program penyetaraan Paket A, Peket B, dan Paket C selanjutnya 4 orang atau $13.33 \%$ tidak setujua dan 8 orang atau $26.66 \%$ responden menjawab ragu-ragu terhadap upaya yang dilakukan pemerintah dalam hal menfasilitasi penyelenggaraan pendidikan non formal dilakukan dalam rangka mengingkatkan kesadaran masyarakat dalam mengubah pradigma masyarakat dalam memandang pentingnya pendidikan formal.

Berdasarkan keterangan dan penjelasan di atas maka dalam pandangan penulis bahwa peneyelenggaraan pendidikan non formal dapat dijadikan saran oleh pemerintah dalam menggambarkan bahwa pendidikan itu sangat penting untuk peningkatan sumber daya manusia dan dapat meningkatkan taraf hidup masyarakat. Maka oleh karena itu setiap uapaya yang dilakukan pemerintah dalam meningkatkan kesadaran masyarakat di DesaLatawe haru bersinergi antara upaya yang satu dengan yang lainya agar saling melengkapi.

\section{PENUTUP}

\section{Kesimpulan}

Berdasarkan hasil penelitian dan pembahasan tentang persepsi masyarakat nelayan pesisir DesaLataweterhadap pentingnya pendidikan formal maka dapat disimpulkan sebagai berikut:

1. Persepsi atau pandangan masyarakat nelayan pesisir DesaLatawe terhadap pentingnya pendidikan formal secara umum masih rendah karena dipengaruhi oleh beberapa faktor di antaranya pengetahuan masyarakat, faktor ekonomi yang rendah, motivasi dan perhatian pemerintah dalam pendidikan pada masyarakat DesaLatawe yang masih minim. Adapun faktor ekonomi adalah faktor yang sangat dominan yang mempengaruhi persepsi masyarakat dalam memandang pentingnya pendidikan formal yaitu sebanyak 20 orang atau $66.66 \%$ responden memberikan tanggapan bahwa faktor ekonomi berupa keterbatasan ekonomi menjadi penyebab tidaknya kepedulian masyarakat 
dalam memandang pentingnya pendidikan formal.

2. Upaya yang dilakukan pemerintah dalam upaya meningkatkan kesadaran masyarakat nelayan pesisir DesaLatawe dalam memandang pentingnya pendidikan formal mencakup sosialisasi program bantuan pemerintah dalam pendidikan, pemberdayaan masyarakat melalui cara melibatkan orang tua dalam mendorong anaknya untuk menempuh pendidikan formal dan penyerlenggaraan pendidikan non formal. Adapun upaya yang cukup efektif adalah pemberdayaan masyarakat melalui cara melibatkan orang tua untuk mendorong anakanya mengikuti pendidikan formal yaitu melalui jalur sekolah dengan tanggapan responden sebanyak15 atau $73.33 \%$ memberikan tanggapan dilibatkan dalam mendorong anaknya mengikuti pendidikan formal yang diselenggarakan disekolah.

Adapun saran penulis dalam penelitian ini antara lain sebagai berikut:

\section{Kepada Pihak Masyarakat}

Kepada masyarakat secara umum dan masyarakat nelayan pesisir Desa Latawe khususnya agar terus berupaya memberikan dorongan kepada anak-anak usia sekolah agar memiliki keinginan atau motifasi menempuh pendidikan formal dalam rangka peningkatan sumber daya manusia.

\section{Kepada pihak pemerintah}

Kepada pemerintah agar terus mengupayakan program bantuan pendidikan yang tepat sasaran khsusnya kepada masyarakat pesisir yang masih mengalami ketertinggalan dalam hal pendidikan sehingga mereka dapat memperoleh kesempatan pendidikan yang sama.

3. Kepada Insan Akademik

Kepada civitas akademik agar dilakukan penelitian lanjutan tentang pendekatan yang lebih efektif dalam upaya meningkatkan kesadaran masyarakat pesisir dalam mengubah paradigma terhadap pemahaman mengenai pentingnya pendidikan formal untuk peningkatan sumber daya manusia

\section{DAFTAR PUSTAKA}

Abdurrahman, Mulyono. 2010. Pendidikan Bagi Anak Berkesulitan Belajar. Jakarta: Rineka Cipta

Arikunto, S. 2013. Prosedur Penelitian. Jakarta: Rineka Cipta.

Abdullah, T dan Lapian, A. B. (ed) (a). (2012). Indonesia dalam Arus SejarahJilid 5: Masa Pergerakan Kebangsaan. Jakarta: PT Ichtiar Baru van Hoeve.

Bimo Walgito. 2002. Pengantar Psikologi Umum. Yogyakarta: Andi Offset

Irwanto.2000. Psikologi Umum. Jakarta: Gramedia Pustaka Utama.

Jalaludin, Rahmat. 2004. Psikologi Komunikasi. Bandung: Remaja Rosdakarya. 
Jurnal Penelitian Pendidikan Geografi Volume 3. No 4 Oktober 2018

J.L. Gilin dan J.P. Gilin dalam syani (2012).Komunikasi Antar

Pribadi.terjemahan daniel

Dhakie.CU.Rajawali:

Jakarta.

Koenjaraningrat, (2012).Metode-

Metode Penelitian

Masyaraka. Gramedia:

Jakarta

Mar'at, 1991. Sikap Manusia

Perubahan Serta

Pengukurannya . Jakarta:

Ghalia Indonesia

Linton. Ralph. 1984 Antropologi: Suatu Penyelidikan Tentang Manusia. Bandung: Jemars

Roucek dan Warren. 1984. Pengantar Sosiologi (diterjemahkan: Sahat Simamora). PT. Bina Aksara. Jakarta

Sarlito Wirawan Sarwono (2008). Psikologi Sosial. Balai Pustaka: Jakarta

Slameto. 2010. Belajar dan FaktorFaktor Yang Mempengaruhinya. Jakarta: PT. Rineka Cipta. 